\title{
Use of Forecasting Models to Predict Producers and Consumers Losses
}

\author{
Mohd Fadzil Shuhaimi bin Ramli ${ }^{1}$, Azman bin Ariffin ${ }^{1}$ \\ ${ }^{I}$ Faculty of Science and Biotechnology, Universiti Selangor, 45600 Bestari Jaya, Selangor, Malaysia.
}

\begin{abstract}
There are several approaches in estimating losses caused by the environmental intervention. The common one is to determine the incomes obtained before and after the perturbation where the difference is the net loss or gain. However, the loss sometimes extends to the consumers who have to pay more for the goods affected by the perturbation following the law of demand and supply. Thus, in fisheries, the losses are determined by the differences of producer and consumer surpluses. The forecasting technique-using time series data collected in 1992-1997 is used to predict landings after perturbation for the next six years. ARIMA $(2,0,2)$ model is found suitable for the forecasting to perform. It is suggested that in the situation where the landings trend is already decreasing even before the perturbation, forecasting technique is used to discern the losses. The reason being, the decreasing trend after perturbation is likely to be perceived as naturally caused thus does not merit losses claim.
\end{abstract}

Keywords: Forecasting, ARIMA models, fish landings

\section{Introduction}

Estimating losses due to pollution caused by the perpetrators sometime could be too simplistic. For example, when fishers caught lesser fish than what they used to get without the intervention, the difference is regarded as a loss. More often the task of estimating the losses is made difficult when there is no proper record of income data before the intervention. Thus, estimator has to rely solely on the information given by the fishers during the interviews. It is then expected, by using this method, claiming compensation is open for debate especially when the perpetrator is accusing over-estimation.

In this paper, the actual environmental incident occurred in 1997-1998 is used as an example to demonstrate how forecasting technique may be useful in estimating income losses. Fish is the commodity both benefited by the producers, the fishers and consumers who bought it in the markets. Therefore, fishers are not the only one making loss since consumers in time of perturbation have to pay more for the fishes following the law of demand and supply [1]. Since fishers are producers, their losses can be explained in terms of reduced producers' surplus. Consumers who purchased fish for consumption had to pay more than before, regarded it as a loss as well since their consumer surplus had reduced.

The benefits gained or lost is practicable to be assessed by comparing the differences between before and after the intervention. This study chooses the periods six years before (1992-1997) and six years after (19982003) the perturbation since it associated with the land reclamation project in South Manjung, Perak [2]. The objective of this study is to estimate losses using forecasting technique of ARIMA time series model [3] and to construct fish landing data which represented the amount that was forecasted to be landed in the absence of perturbation. Comparing forecasted data with the actual fish landed; consumer and producer surpluses are gauged.

\subsection{Data collection}

\section{Materials and Methods}

Demand and supply curves for fish were constructed using data extracted from the Annual Fisheries Statistics (AFS) published by Department of Fisheries Malaysia (DOF) for the period between 1992 and 2003 with the exception of fish landings and prices of South Manjung where they were obtained raw from unpublished statistical reports of Fisheries District Office of Manjung (FDOM), Perak recorded on the official forms number SMPP 1/8_Pin.1/96 and SMPP 4/86 respectively. Due to lack of information and data on fish that were sold in different forms at other market outlets, (canned, reduced, cured, etc.) this study limited itself to the study of demand and supply of fish that were transacted at landing points and fish markets. Hence, the actual total amount of fish sold in South Manjung markets is shown in Table 1.0.

The demand scatter diagram (or scattergram) of retail price per kg against the quantity demanded over a 11-year period is shown in Fig. 1.0. Since the scattergram exhibits a strong association between the two variables [4] .It is assumed that the curve is characterized by a linear demand function. However, [5] suggested that the scattergram alone is not a confirmatory statistical procedure. The scattergram allows the researcher to check visually the validity of a general linear confirmatory procedure that is being used (such as correlation or 
regression). To determine whether there is a genuine relationship or not, Pearson's product-moment correlation coefficient parametric test was applied to retail price against the quantity fish demanded $(\mathrm{r}=-0.734, P=0.024)$. The negative relationship was significant at the $5 \%$ level indicating the nature of demand function, such that as price of fish increases, the less is being demanded.

Table 1.0 : The actual amount of fish sold in the markets of South Manjung

\begin{tabular}{|c|c|c|c|c|}
\hline Year & $\begin{array}{l}\text { Total Fish } \\
\text { Landing } \\
(\mathrm{kg})\end{array}$ & $\begin{array}{c}\text { Fish } \\
\text { Disposition } \\
\text { Fraction }^{* *} \\
\text { (Fresh and } \\
\text { Chilled) }\end{array}$ & $\begin{array}{l}\text { Total Fish } \\
\text { Sold } \\
\text { In Markets } \\
(\mathrm{kg})\end{array}$ & $\begin{array}{l}\text { Average } \\
\text { Retail } \\
\text { Price } \\
(\mathrm{RM} / \mathrm{kg})\end{array}$ \\
\hline 1992 & $4,559,650.0$ & 0.66 & $3,009,369$ & 6.05 \\
\hline 1993 & $4,105,000.0$ & 0.39 & $1,600,950$ & 8.25 \\
\hline 1994 & $6,998,460.0$ & 0.53 & $3,709,184$ & 5.0 \\
\hline 1995 & $7,216,680.0$ & 0.58 & $4,185,674$ & 5.30 \\
\hline 1996 & $8,462,560.0$ & 0.55 & $4,654,408$ & 5.20 \\
\hline 1997 & $7,109,070.0$ & 0.56 & $3,981,079$ & 5.50 \\
\hline 1998 & $5,481,180.0$ & 0.54 & $2,959,837$ & 4.87 \\
\hline 1999 & $4,395,940.0$ & 0.49 & $2,154,011$ & 5.89 \\
\hline 2000 & $6,003,620.0$ & 0.50 & $3,001,810$ & 6.27 \\
\hline 2001 & $5,518,590.0$ & 0.19 & $1,048,532$ & 7.12 \\
\hline 2002 & $4,081,100.0$ & 0.15 & 612,165 & 8.20 \\
\hline 2003 & $5,636,210.0$ & 0.22 & $1,239,966$ & 7.30 \\
\hline
\end{tabular}

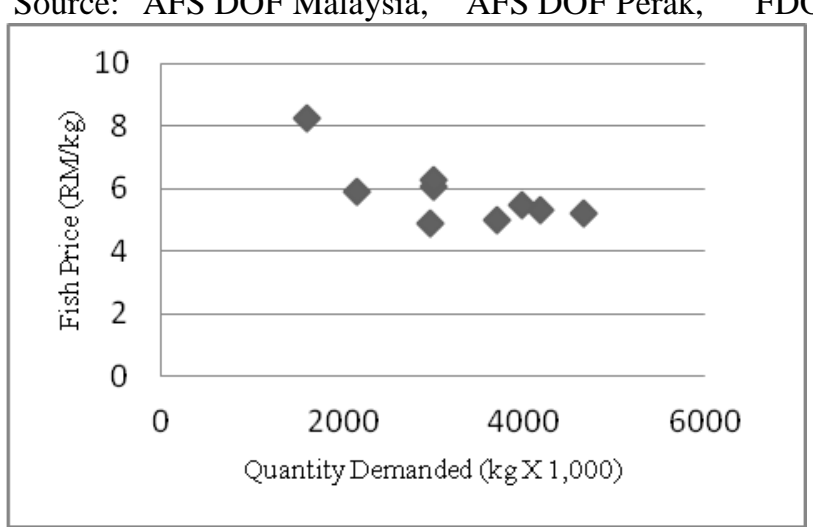

Fig. 1.0: The scattergram of fish price (retail) against quantity demanded

The relationship between price $\left(\mathrm{P}_{t}\right)$ and quantity demand $\left(\mathrm{Q}_{t}\right)$ of fish was $\mathrm{P}_{t}=8.318-7.70 \mathrm{E}-07 \mathrm{Q}_{\mathrm{t}}$. The consumers' surplus of a particular year was represented by the area under the curve but above the retail price; that is, consumers' surplus, $\mathrm{CS}_{\mathrm{t}}=1 / 2\left[8.318-\mathrm{P}_{\mathrm{t}}\right]\left[\mathrm{Q}_{\mathrm{t}}\right]$. The net consumers' surplus is thus given by NCS $=\sum \mathrm{CS}_{\mathrm{t}}$ which fot the years 1992 to year 1997 was RM 28,802,337 and between 1998 and 2003 was RM 12,086,913 (Table 2.0), indicating a loss of RM 16,715,424 as a result of change of environment (land reclamation) after 1997.

Table 2.0: The difference of consumer surplus before and after perturbation

\begin{tabular}{|c|c|c|c|}
\hline $\begin{array}{c}\text { Year } \\
(\mathrm{i})\end{array}$ & $\begin{array}{c}\text { Retail Price- } \\
\text { RM }\left(\mathrm{P}_{\mathrm{t}}\right)\end{array}$ & $\begin{array}{c}\text { Quantity Demanded- } \\
\mathrm{kg}\left(\mathrm{Q}_{\mathrm{t}}\right)\end{array}$ & $\begin{array}{c}\text { Consumer Surplus- } \\
\mathrm{RM}\left(\mathrm{CS}_{\mathrm{t}}\right)\end{array}$ \\
\hline 1992 & 6.05 & $3,009,369$ & $3,412,624$ \\
1993 & 8.25 & $1,600,950$ & 54,432 \\
1994 & 5.0 & $3,709,184$ & $6,153,536$ \\
1995 & 5.30 & $4,185,674$ & $6,316,182$ \\
1996 & 5.20 & $4,654,408$ & $7,256,222$ \\
1997 & 5.50 & $3,981,079$ & $5,609,340$ \\
& & & $\sum C S_{t}=28,802,337$ \\
\hline Total & & & \\
& & & \\
& & & \\
\hline 1998 & 4.87 & $2,959,837$ & $2,102,759$ \\
1999 & 5.89 & $3,001,011$ & $3,073,859$ \\
2000 & 6.27 & & \\
\hline
\end{tabular}




\begin{tabular}{|c|c|c|c|}
\hline 2001 & 7.12 & $1,048,532$ & 628,070 \\
2002 & 8.20 & 612,165 & 36,117 \\
2003 & 7.30 & $1,239,966$ & 631,142 \\
& & & $\sum C S_{t}=$ \\
\hline Total & & & $12,086,913$ \\
& & & \\
\hline
\end{tabular}

The supply scattergram over 11 year period between ex-vessel price per $\mathrm{kg}$ and the quantity supplied is shown in Fig. 2.0. The relationship between supply is designated by $\mathrm{P}_{t}=2.71+2.989 * 10^{-7} \mathrm{Q}_{t}$, where $\mathrm{P}_{t}$ is the exvessel price, $\mathrm{Q}_{\mathrm{t}}$ is the quantity supplied and $t$ is year $1992 \ldots, \mathrm{n}=2003$. The producers' surplus is the area below the ex-vessel price but above the supply function curve. Thus, the producers' surplus is given by $\mathrm{PS}_{t}=1 / 2\left[\mathrm{P}_{t}-\right.$ 2.71] $\left[Q_{t}\right]$, where $P_{t}$ is the ex-vessel price, $Q_{t}$ is the quantity sold and $t$ is year $1992 \ldots, n=2003$. The net producers' surplus, NPS $=\sum$ PS $_{\mathrm{t}}$. For the years $1998-2003$ was lower than that in years 1992-1997 indicating a loss of RM 13,283,609.10 to the fishers (Table 3.0).

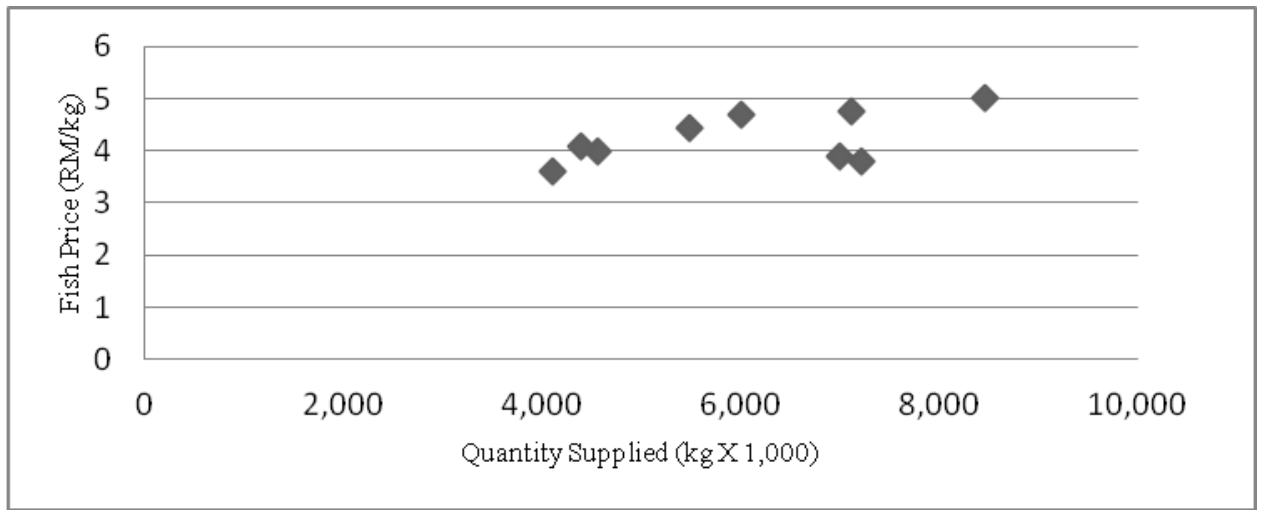

Fig. 2.0: The Scattergram of fish price (ex-vessel) against quantity supplied

Table 3.0: The Difference of producer surplus before and after perturbation

\begin{tabular}{|c|c|c|c|}
\hline Year & $\begin{array}{c}\text { Quantity }(\mathrm{kg}) \\
\left(\mathrm{Q}_{\mathrm{t}}\right)\end{array}$ & $\begin{array}{c}\text { Ex-vessel } \\
\text { Price }(\mathrm{RM}) \\
\left(\mathrm{P}_{\mathrm{t}}\right)\end{array}$ & $\begin{array}{c}\text { Producer } \\
\text { Surplus } \\
(\mathrm{RM}), \\
\mathrm{PS}_{\mathrm{t}}=1 / 2\left[\mathrm{P}_{\mathrm{t}}-\right. \\
2.71]\left[\mathrm{Q}_{\mathrm{t}}\right]\end{array}$ \\
\hline 1992 & $4,559,650$ & 4.0 & $2,940,974$ \\
1993 & $4,105,000$ & 3.62 & $1,867,775$ \\
1994 & $6,998,460$ & 4.8 & $7,313,391$ \\
1995 & $7,216,680$ & 5.1 & $8,623,933$ \\
1996 & $8,462,560$ & 5.0 & $9,689,631$ \\
1997 & $7,109,070$ & 4.77 & $7,322,342$ \\
& & & $\sum P S_{t}=$ \\
& & & $37,758,046$ \\
\hline & & 4.43 & $4,713,815$ \\
1998 & $5,481,180$ & 4.1 & $3,055,178$ \\
2009 & $4,395,940$ & 4.7 & $5,973,602$ \\
2001 & $6,003,620$ & 4.43 & $4,745,987$ \\
2002 & $5,518,590$ & 4.0 & $2,632,310$ \\
2003 & $4,081,100$ & 3.9 & $3,353,544$. \\
\hline & $5,636,210$ & & $\sum P S_{t}=$ \\
& & & $24,474,436$ \\
\hline
\end{tabular}

Producers' surplus can also be estimated by the accounting method. The net profit of fishers is the difference between total revenue and the total variable cost. The total revenue is the amount fishers get by selling their fish at a given price. This net profit is the producers' surplus and is given by $\mathrm{PS}_{t}=\mathrm{TR}_{\mathrm{t}}-\mathrm{TVC}_{\mathrm{t}}$, where TR is the total revenue, TVC is the total variable cost and $t$ is the year 1992, 1993, $1994 \ldots, n=2003$. The TVC of a particular year is given by $\mathrm{TVC}_{t}=$ operating cost per fishing trip X 20 fishing days $\mathrm{X} 12$ months $\mathrm{X}$ number of fishing vessels [6]. For example, in 1992, there were 500 fishing vessels, each spending an average $\mathrm{RM} 39.87$ for every fishing trip. Therefore, $\mathrm{TVC}_{1992}=\mathrm{RM} 39.87 * 20 * 12 * 500=\mathrm{RM} 4,784,400$. NPS for the 
years 1992 - 1997 was RM 150,564,580 compared with RM 57,292,913 between 1998 - 2003, indicating a loss of RM 93,271,667 as a result of the projects. (Table 4.0).

Table 4.0: Accounting method: The difference of producer surplus before and after perturbation

\begin{tabular}{|c|c|c|c|}
\hline $\begin{array}{l}\text { Year/No.of } \\
\text { Vessels } \\
\text { (i ) }\end{array}$ & $\begin{array}{c}\text { Total Revenue } \\
\left(\mathrm{TR}_{\mathrm{i}}\right) \\
\mathrm{RM}\end{array}$ & $\begin{array}{c}\text { Total Variable } \\
\text { Cost } \\
\left(\mathrm{TVC}_{\mathrm{i}}\right) \\
\text { RM }\end{array}$ & $\begin{array}{c}\text { Producers' } \\
\text { Surplus } \\
\left(\mathrm{PS}_{\mathrm{i}}\right) \mathrm{TR}_{\mathrm{i}}-\mathrm{TVC}_{\mathrm{i}} \\
\mathrm{RM}\end{array}$ \\
\hline $1992 / 500$ & $18,238,600$ & $4,784,400$ & $13,454,200$ \\
\hline $1993 / 525$ & $14,860,100$ & $5,128,200$ & $9,731,900$ \\
\hline $1994 / 483$ & $33,592,608$ & $4,661,143$ & $28,931,465$ \\
\hline $1995 / 511$ & $36,805,068$ & $4,979,184$ & $31,825,884$ \\
\hline $1996 / 515$ & $42,312,800$ & $5,079,960$ & $37,232,840$ \\
\hline $1997 / 455$ & $33,910,263$ & $4,521,972$ & $29,388,291$ \\
\hline \multicolumn{3}{|c|}{$\sum \mathrm{PS}_{\mathrm{i}}$} & $150,564,580$ \\
\hline $1998 / 515$ & $24,281,627$ & $8,203,332$ & $16,078,295$ \\
\hline $1999 / 529$ & $18,023,354$ & $8,498,702$ & $9,524,651$ \\
\hline $2000 / 898$ & $28,217,014$ & $15,392,438$ & $12,824,576$ \\
\hline $2001 / 802$ & $24,447,353$ & $14,601,533$ & $9,845,820$ \\
\hline $2002 / 792$ & $16,324,400$ & $14,731,200$ & $1,593,200$ \\
\hline $2003 / 770$ & $21,981,219$ & $14,554,848$ & $7,426,371$ \\
\hline$\sum \mathrm{PS}_{\mathrm{i}}$ & & & $57,292,913$ \\
\hline
\end{tabular}

\subsection{Losses measured on forecasted data}

The forecasting technique was used to forecast fish landings, $Q_{t}$, in years $t=1998,1999,2000 \ldots n=$ 2003 and then fitting the forecasted values into the demand equation $P_{t}=8.318-7.70 \mathrm{E}-07 \mathrm{Q}_{t}$. Table 5.0 shows the time-series data of fish landings collected on a monthly basis in South Manjung. The consumer surplus is then obtained by inserting the value $\mathrm{P}_{t}$ and $\mathrm{Q}_{\mathrm{t}}$ into $\mathrm{CS}_{\mathrm{t}}=1 / 2\left[8.318-\mathrm{P}_{\mathrm{t}}\right]\left[\mathrm{Q}_{\mathrm{t}}\right]$. Similarly, the PS is obtained by imputing $Q_{t}$ into the supply equation $P_{t}=2.71+2.9890 E-07 Q_{t}$ and the $P_{t}$ obtained into $P_{t}=1 / 2\left[P_{t}-2.71\right]\left[Q_{t}\right]$. Since the interest here is to measure the difference in benefits received by the consumer between the forecasted and the actual fish landings, the consumer net benefit is given by $\mathrm{CNB}_{\mathrm{FA}}=\sum_{t=1998}^{n=2003} \mathrm{FCS}_{\mathrm{t}}-\sum_{t=1998}^{n=2003} \mathrm{ACS}_{\mathrm{t}}$ where $\mathrm{FCS}_{\mathrm{t}}$ is the forecasted consumer surplus at time $t$ and $\mathrm{ACS}_{\mathrm{t}}$ is the actual consumer surplus at time $t$. A similar treatment is also applied to the producer's net benefit/loss, i.e. $\mathrm{PNB}_{\mathrm{FA}}=\sum_{t=1998}^{n=2003} \mathrm{FPS}_{\mathrm{t}}-\sum_{t=1998}^{n=2003} \mathrm{APS}_{\mathrm{t}}$, where $\mathrm{P}$ is the producer. The Total Economic Surpluses (TES), i.e. the surpluses benefited/lost by the society, is then given by $\mathrm{TES}=\mathrm{CNB}_{\mathrm{FA}}+\mathrm{PNB}_{\mathrm{FA}}$.

Table 5.0: Monthly time-series data of fish landings of South Manjung

\begin{tabular}{|c|c|c|c|c|c|c|c|c|c|c|}
\hline \multirow[b]{2}{*}{ Months } & \multicolumn{10}{|c|}{ Years } \\
\hline & 1994 & 1995 & 1996 & 1997 & 1998 & 1999 & 2000 & 2001 & 2002 & 2003 \\
\hline Jan. & 361.16 & 338.1 & 446.05 & 535.62 & 364.46 & 451.79 & 479.21 & 397.21 & 294.44 & 370.18 \\
\hline Feb. & 354.86 & 856.21 & 603.69 & 398.35 & 404.14 & 380.98 & 415.64 & 412.16 & 273.7 & 400.08 \\
\hline Mar. & 572.36 & 925.15 & 888.83 & 791.88 & 394.33 & 417.62 & 418.12 & 426.81 & 295.41 & 500.58 \\
\hline Apr. & 1273.95 & 779.26 & 635.62 & 1012.44 & 326.45 & 371.87 & 534.01 & 567.39 & 368.91 & 499.63 \\
\hline May & 1270.3 & 784.87 & 648 & 610.72 & 461.95 & 305.25 & 497.03 & 590.79 & 259.69 & 561.39 \\
\hline Sune & 529.45 & 591.58 & 814.56 & 934.71 & 586.27 & 399.87 & 412.42 & 519.7 & 270.76 & 504.1 \\
\hline July & 353.25 & 680.95 & 928.44 & 618.21 & 547.17 & 393.04 & 474.89 & 350.25 & 347.56 & 452.72 \\
\hline Aug. & 419.66 & 371.02 & 649.87 & 523.48 & 576.71 & 329.31 & 470.53 & 533.65 & 463.96 & 452.56 \\
\hline Sep. & 500.37 & 373.64 & 733.48 & 356.14 & 536.15 & 307.97 & 465.31 & 639.48 & 306.78 & 598.91 \\
\hline Oct. & 532.44 & 513.91 & 662.46 & 392.23 & 518.2 & 321.31 & 528.05 & 409.72 & 404.01 & 412.44 \\
\hline Nov. & 427.5 & 513.77 & 776.31 & 457.67 & 421.2 & 316.67 & 699.35 & 347.83 & 396.06 & 420.64 \\
\hline Dec. & 403.16 & 488.22 & 675.26 & 477.61 & 344.14 & 400.25 & 609.06 & 322.89 & 399.73 & 462.98 \\
\hline & & & & & & & & & & \\
\hline
\end{tabular}

\subsection{Specifying ARIMA model}

\section{Result}

In any time series analysis, a visual plot of the data is usually the first step [7]. Fig. 3.0 is the timeseries plot of monthly landings ( $\mathrm{t}$ ) plotted against time. Landings were not affected by seasons since the patterns show irregular peaks and troughs over time. 


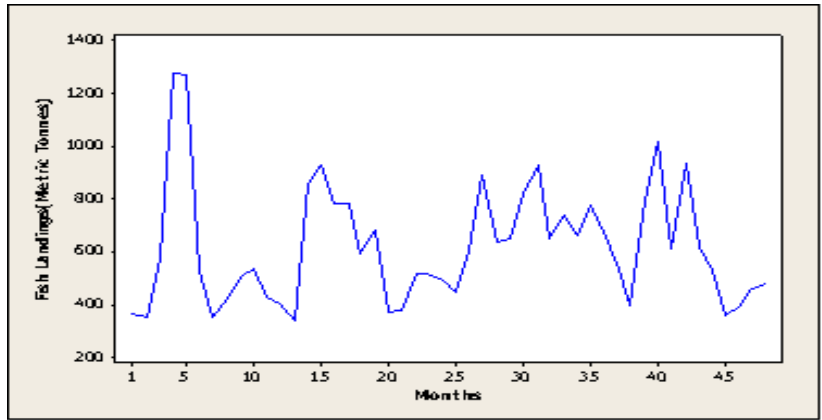

Fig. 3.0: Time-Series plot of South Manjung fish landings between 1994-1997 Note: Months 1-12 (1994), months 13-24 (1995), months 25-36 (1996), and months 37-48 (1997).

Before the ARIMA model can be applied to a time series, it must be assured that the time series is stationary [8]. According to [8], the time-series variable, $X_{t}$, is stationary if, (1) the mean of $X_{t}$ is constant over time, (2) the variance of $X_{t}$ is constant over time, and (3) the simple correlation coefficient between $X_{t}$ and $X_{t-k}$ (also called an autocorrelation function) depends on the length of the lag (k) but on no other variable (for all $\mathrm{k}$ ). The test for equality of variances [9] on the time-series data showed that the $\mathrm{F}_{\max }=6.22$ at $P=0.05$ which is higher than the critical value of $\mathrm{F}_{\max }=5.23(\mathrm{df}=11, \mathrm{k}=4)$ indicating that the variances are significantly different, thus the data were logarithmic transformed. The transformed data (natural logarithm) offered $\mathrm{F}_{\max }=$ 5.10 indicating equal variances among the samples. To conclude whether the time series is stationary or not can be done by studying the graph of the correlogram of the series [10]. The correlogram is the plot of an autocorrelation function, ACF against the lag length . Fig. 4.0 is the correlogram of the log-transformed monthly fish landings time series from 1994 to 1997. The time series shows no differencing $(d=0)$ as it signifies a stationary feature since the ACF drops off as $k$, the number of lags becomes large which is usually not the case for a nonstationary series [3] or as put by [8], a nonstationary series will show little tendency for the ACFs to decrease in size as the number of lags increases. The correlogram is produced by using the Minitab program and plugging the maximum number of lags $=48$.

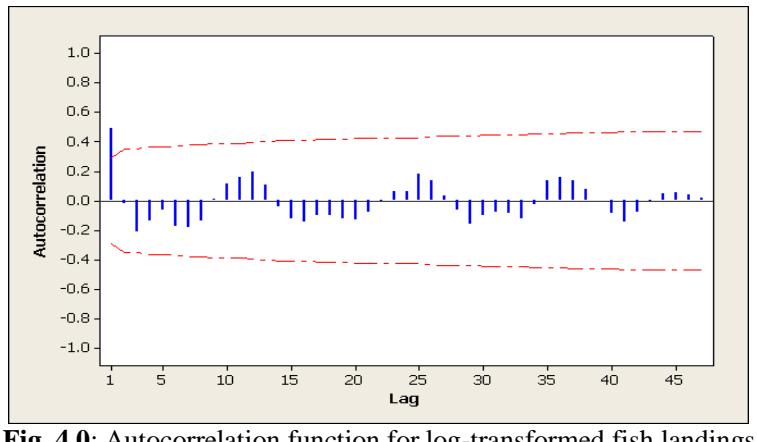

Fig. 4.0: Autocorrelation function for log-transformed fish landings ( with 5\% significance limits for the autocorrelations)

The next step is to arrive at the tentative ARIMA model that is, to choose the integer values for $p$ and $q$ having decided that $d=0$. This is the identification process where the ACF and PACF are used to estimate $p$ and $q$. Fig. 5.0 is correlogram of the PACF plotted against the lag length. In particular, the last lag before the PACF tends to zero is typically a good value for $p$, and the last lag before the ACF tends to zero is typically a good value for $q$ [8]. Thus, in this case the tentative ARIMA model is ARIMA $(2,0,1)$ or an equivalent to $\operatorname{ARMA}(2,1)$.

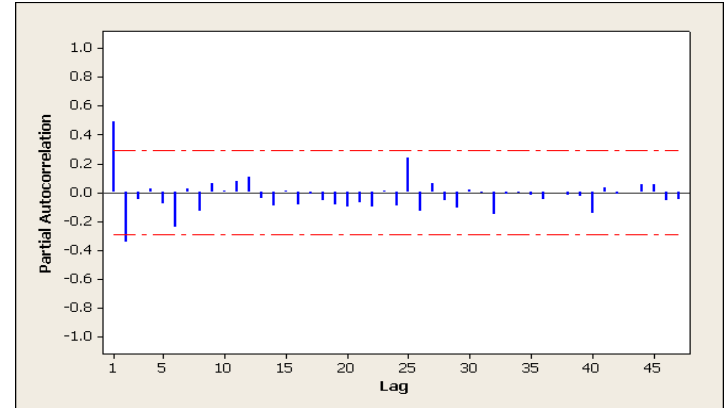

Fig. 5.0: Partial autocorrelation function for log-transformed fish landings (with 5\% significance limits for the partial autocorrelations) 
The tentative ARMA $(2,1)$ was then fitted using the Minitab program and followed by the diagnostic checking on the residuals of the ACF and PACF. Other ARMA models such as ARMA $(1,1)$, ARMA $(2,1)$, ARMA $(1,2)$, ARMA $(2,2)$ were also fitted and diagnosed in similar fashion in attempt to select the best model. It was found that ARMA $(2,2)$ represents the best model having the lowest Mean Square Error value (MSE= 0.08298) and the highest Box-Ljung statistic of nonsignificant level of $\mathrm{P}=0.741$ ( at lag 12) indicating that the residuals appeared to be uncorrelated. The Minitab forecasting procedure for the next 72 months (1998 - 2003) was then performed using the model ARMA $(2,2)$ and tabulated in Table 6.0. Thus the total annual fish landings forecasted are 6,569.67 $\mathrm{t}$ in $1998,6,798.69 \mathrm{t}$ in $1999,6,860.05 \mathrm{t}$ in $2000,6,921.01 \mathrm{t}$ in 2001, 6,982.58 $\mathrm{t}$ in 2002 and $7,044.82 \mathrm{t}$ in 2003.

Table 6.0 : The forecasted fish landings

\begin{tabular}{|l|c|c|c|c|c|c|}
\hline & \multicolumn{5}{|c|}{ Annual Forecasted Fish Landings (Metric Tons) } \\
\hline Month & 1998 & 1999 & 2000 & 2001 & 2002 & 2003 \\
\hline January & 501.0635 & 563.9916 & 569.3578 & 574.413 & 579.519 & 584.6821 \\
\hline February & 521.0425 & 564.5332 & 569.7735 & 574.8383 & 579.948 & 585.1149 \\
\hline March & 534.6225 & 565.0302 & 570.1953 & 575.2638 & 580.3773 & 585.548 \\
\hline April & 543.8048 & 565.4994 & 570.6174 & 575.6839 & 580.8069 & 585.9815 \\
\hline May & 550.012 & 565.952 & 571.0398 & 576.11 & 581.2369 & 586.4152 \\
\hline June & 554.2356 & 566.3879 & 571.4568 & 576.5365 & 581.6671 & 586.8493 \\
\hline July & 557.1529 & 566.8242 & 571.8798 & 576.9633 & 582.0977 & 587.2837 \\
\hline August & 559.2013 & 567.2494 & 572.3032 & 577.3846 & 582.5228 & 587.7185 \\
\hline September & 560.6851 & 567.675 & 572.7211 & 577.812 & 582.954 & 588.1535 \\
\hline October & 561.7963 & 568.0952 & 573.145 & 578.2397 & 583.3855 & 588.5889 \\
\hline November & 562.6678 & 568.5158 & 573.5693 & 578.6678 & 583.8174 & 589.0246 \\
\hline December & 563.3828 & 568.9366 & 573.9882 & 579.0961 & 584.2496 & 589.4606 \\
\hline Total & 6569.667 & 6798.69 & 6860.047 & 6921.009 & 6982.582 & 7044.821 \\
\hline
\end{tabular}

\subsection{The forecasted net social benefit}

In the absence of perturbation between period 1998 - 2003, the forecasted total consumer surplus, as the result of the surpluses summed up in those years, was $\sum_{t=1998}^{n=2003} \mathrm{FCS}_{\mathrm{t}}=\mathrm{RM} 15,660,609.67$ while the producer surplus, was $\sum_{t=1998}^{n=2003} \mathrm{FPS}_{\mathrm{t}}=\mathrm{RM} 42,253,890.14$ (Table 7.0). The actual surpluses gauged for the same period of time, indicate a lower consumer surplus $\left(\sum_{t=1998}^{n=2003} \mathrm{ACS}_{\mathrm{t}}=\mathrm{RM} 12,086,913.00\right)$ and producer surplus $\left(\sum_{t=1998}^{n=2003} \mathrm{APS}_{\mathrm{t}}=\right.$ RM 24,474,436.90). Thus, $\mathrm{CNB}_{\mathrm{FA}}=\mathrm{RM} 15,660,609.67-\mathrm{RM} 12,086,913.00=\mathrm{RM} 3,573,696.67$, and likewise, the $\mathrm{PNB}_{\mathrm{FA}}=\mathrm{RM} 42,253,890.14-\mathrm{RM} 24,474,436.90=17,779,453.24$. Therefore, the $\mathrm{NSB}=\mathrm{CNB}_{\mathrm{FA}}+\mathrm{PNB}_{\mathrm{FA}}=$ -RM 21,353,149.91. The negative sign of the NSB indicates a loss to the society since it is the value that they should receive in the absence of perturbation.

Table 7.0 : The forecasted consumer and producer surpluses.

\begin{tabular}{|c|c|c|c|c|c|c|c|}
\hline Year & $\begin{array}{c}\mathrm{Q}(\mathrm{t}) \\
\text { Forecasted } \\
\text { Landing }(\mathrm{Kg})\end{array}$ & $\begin{array}{c}\text { Fish } \\
\text { Disposition } \\
\text { Fraction } \\
\text { (Fresh and } \\
\text { Chilled) }\end{array}$ & $\begin{array}{l}\text { Total Fish } \\
\text { Sold in } \\
\text { Markets (Kg) }\end{array}$ & $\begin{array}{c}\mathrm{P}(\mathrm{t}), \\
\text { Consumer } \\
\text { Price } \\
(\mathrm{RM} / \mathrm{Kg})\end{array}$ & $\begin{array}{c}\text { CS(t), } \\
\text { Consumer } \\
\text { Surplus (RM) }\end{array}$ & $\begin{array}{c}\mathrm{P}(\mathrm{t}), \\
\text { Producer } \\
\text { Price } \\
(\mathrm{RM} / \mathrm{Kg})\end{array}$ & $\begin{array}{c}\text { PS(t), } \\
\text { Producer } \\
\text { Surplus (RM) }\end{array}$ \\
\hline 1998 & 6569667 & 0.54 & 3547620.18 & 5.59 & 4845459.442 & 4.67 & 6450340.385 \\
\hline 1999 & 6798690 & 0.49 & 3331358.1 & 5.75 & 4272709.514 & 4.74 & 6907905.655 \\
\hline 2000 & 6860047 & 0.5 & 3430023.5 & 5.68 & 4529548.566 & 4.76 & 7033153.592 \\
\hline 2001 & 6921009 & 0.19 & 1314991.71 & 7.31 & 665743.231 & 4.78 & 7158709.636 \\
\hline 2002 & 6982582 & 0.15 & 1047387.3 & 7.51 & 422352.7601 & 4.8 & 7286651.66 \\
\hline 2003 & 7044821 & 0.22 & 1549860.62 & 7.12 & 924796.1574 & 4.82 & 7417129.212 \\
\hline Total & & & & & 15660609.67 & & 42253890.14 \\
\hline
\end{tabular}

When the accounting method was used to calculate the producer surpluses based on the forecasted fish landings, the forecasted producer surplus was given by $\sum_{t=1998}^{n=2003} \mathrm{FPS}_{\mathrm{t}}=\mathrm{RM} 120,132,760$ compared to the actual producer surplus, $\sum_{t=1998}^{n=2003} \mathrm{APS}_{\mathrm{t}}=\mathrm{RM} 57,292,915$ (Table 8.0). Thus the $\mathrm{PNB}_{\mathrm{FA}}=\mathrm{RM} 120,132,760-\mathrm{RM}$ 
$57,292,915=\mathrm{RM} 62,839,844$. Here, $\mathrm{NSB}=\mathrm{CNB}_{\mathrm{FA}}+\mathrm{PNB}_{\mathrm{FA}}=-\mathrm{RM} 66,413,541$ Again, the minus value indicates the loss to the society.

Table 8.0: Producer surplus by accounting method.

\begin{tabular}{|c|c|c|c|c|c|c|}
\hline & $\begin{array}{l}\text { Year/No. of } \\
\text { Vessels }\end{array}$ & $\begin{array}{ll}\mathrm{Q}(\mathrm{t}), & \text { Fish } \\
\text { Landings } & \end{array}$ & $\begin{array}{l}\mathrm{P}(\mathrm{t}), \quad \text { Producer } \\
\text { Price }(\mathrm{RM} / \mathrm{Kg})\end{array}$ & $\begin{array}{lr}\text { TR(t), } & \text { Total } \\
\text { Revenue }(\mathrm{RM})\end{array}$ & $\begin{array}{ll}\text { TVC(t), } & \text { Total } \\
\text { Variable } & \text { Cost } \\
(\mathrm{RM}) & \\
\end{array}$ & $\begin{array}{l}\text { PS(t), Producer } \\
\text { Surplus (RM) }\end{array}$ \\
\hline \multirow{5}{*}{ Forecasted } & $1998 / 515$ & 6569667 & 4.67 & 30680344.89 & 8203332 & 22477012.89 \\
\hline & $2000 / 898$ & 6860047 & 4.76 & 32653823.72 & 15392438 & 17261385.72 \\
\hline & $2001 / 802$ & 6921009 & 4.78 & 33082423.02 & 14601533 & 18480890.02 \\
\hline & $2002 / 792$ & 6982582 & 4.8 & 33516393.6 & 14731200 & 18785193.6 \\
\hline & Total & & & & & 120132760.1 \\
\hline \multirow{5}{*}{ Actual } & $1998 / 515$ & 5481180 & 4.43 & 24281627.4 & 8203332 & 16078295.4 \\
\hline & $1999 / 529$ & 4395940 & 4.1 & 18023354 & 8498702 & 9524652 \\
\hline & $2000 / 898$ & 6003620 & 4.7 & 28217014 & 15392438 & 12824576 \\
\hline & $2001 / 802$ & 5518590 & 4.43 & 24447353.7 & 14601533 & 9845820.7 \\
\hline & $2002 / 792$ & 4081100 & 4 & 16324400 & 14731200 & 1593200 \\
\hline
\end{tabular}

\section{Conclusion}

This study offered two approaches to compare the state of fisheries with regard to the introduction of perturbation: (1) the total surpluses of six-year period before perturbation was compared with the total surpluses of six-year period after the perturbation, and (2) the predicted surpluses of six-year period after perturbation was compared with the actual surpluses of the same period. The first approach expected that the surpluses received by the society after perturbation should be at least equal in the absence of perturbation while the second approach proposed that the difference between predicted and actual surpluses was the benefit that should be received by the society in the absence of perturbation. Which of these approaches is superior to another is based on whether fish landings, which parallel surpluses, were stable or increased in the absence of perturbation. If it is the case, then comparing surpluses before perturbation may provide more discerning results. Alternatively, forecasted data are preferred if the trend is in a decreasing pattern, as it can be inferred that the difference in surpluses between before and after periods may be as a result of natural causes so that the surpluses from the before period may no longer be appropriate for comparison with the after period.

Although this study has used the demand curve in search of consumer surplus, the accounting method for producer surplus together with the before-after perturbation comparison, other approaches should also be considered. For example, in the situation where variable costs are impossible to be obtained, whereas there are data on fish landings and the relevant prices that permit the construction of the supply curve, then producer surplus can be presented. Another scenario, the forecasting technique can be useful, as explained earlier, when there is an indication that catch is declining during the before period, and expected to continue even after the perturbation period, may be as a result of natural causes. As such, the predicted surpluses measured in the after period can be used to compare with actual surpluses where the difference is the benefit before the perturbation.

\section{Acknowledgment}

The author wishes to thank the Universiti Selangor, Malaysia in general and the Dean of Faculty of Science and Biotechnology in particular for encouragement and assistance given during the preparation of this paper.

\section{References}

[1] A. Marshall, Principles of economics (8 th edition) (Macmillan,London, 1920)

[2] Perunding Utama Sdn. Bhd., Detailed environmental impact assessment for proposed Lekir coastal development. (Desa Kilat Sdn.Bhd (Kuala Lumpur, 1977)

[3] R. S. Pindyck, and D.L. Rubinfeld, Econometric models and economic forecasts. (Irwin/McGraw-Hill,U.S.A., 1998)

[4] P.Jedamus, ; R. Frame and R. Taylor , Statistical analysis for business Decisions (McGraw-Hill Book Company, USA pp. 213, 1976)

[5] R.L. Miller, C. Acton, D.A. Fullerton and J. Maltby, SPSS for social scientists (Palgrave Macmillan, UK, 2002).

[6] LKIM , Laporan kajiansSosioekonomi nelayan 1995 (Kuala Lumpur: Lembaga Kemajuan Ikan Malaysia, Kementerian Pertanian Malaysia, 1998)

[7] D.N. Gujarati,. Basic econometrics (Singapore: McGraw-Hill, Inc., 1995)

[8] A.H Studenmund, Using econometrics: a practical guide. (Addison-Wesley, U.S.A., 1997)

[9] C.P. Wheater, and P.A. Cook, Using statistics to understand the environment (London: Routledge, Taylor \& Francis Group, 2003)

[10] G.S. Maddala, Introduction to econometrics. (John Wiley \& Sons, Ltd, Chichester, 2001) 